\title{
Biotic enrichment of intertidal sediments by experimental aggregates of the deposit-feeding bivalve Macoma balthica*
}

\author{
Karsten Reise \\ Biologische Anstalt Helgoland, Litoralstation, D-2282 List, Federal Republic of Germany \\ and \\ 2. Zoologisches Institut der Universität Göttingen, D-3400 Göttingen, Federal Republic of Germany
}

\begin{abstract}
Experimental aggregates of the bivalve Macoma balthica, established on a sandy tidal flat in the North Sea, are preferentially colonized by small zoobenthos. The tellinids stay buried at 3 to $6 \mathrm{~cm}$ while their long inhalant siphons pick up deposits from the surface. The short exhalant siphons terminate within the sediment. High abundance of diatom-feeding Turbellaria at the surface, and bacteria-feeding and predatory species in the subsurface suggest enhanced growth of microalgae, bacteria and their grazers, stimulated by $M$. balthica. No such 'gardening' effects are observed within aggregates of the suspension-feeding cockle Cerastoderma edule, where exhalant siphons are flush with the surface. Both bivalve aggregates, however, displaced the tube-dwelling polychaete Pygospio elegans.
\end{abstract}

\section{INTRODUCTION}

The ecological role of organisms cannot be measured solely in terms of their population metabolism. Organisms may also exclude or promote co-existing species. Such effects can be demonstrated in field experiments, where representatives of one species are added or removed and the effect on co-existing organisms are recorded. In this study, I added 2 bivalve species to tidal-flat sediments in the North Sea - representatives of a deposit feeder and a suspension feeder - in order to determine which one exerted more effects on other benthos forms. Do negative effects (competition, food depletion) prevail or are there any positive effects when bivalves arrange in dense assemblages?

Instead of sampling the entire benthos, I singled out Turbellaria and small Polychaeta because of their high number of species, extended vertical ranges in the sediment, and diverse modes of feeding. Particularly in Turbellaria, the gut content is readily visible and species could be assembled into 3 trophic guilds based on observations on the experimental site: bacteriafeeders, diatom-feeders and predators. Turbellaria and small Polychaeta are taken as bioindicators for the

\footnotetext{
- Supported by 'Deutsche Forschungsgemeinschaft' (DFG)

general effects of the experimental addition of bivalves on the tidal flat benthos. At the site these taxa comprise $11 \%$ and $4 \%$ of all Metazoa, respectively.

One polychaete species suffered competitive displacement while another polychaete and all Turbellaria became more abundant when the deposit-feeding bivalve was added. The trophic guilds of Turbellaria suggest that the deposit-feeding bivalve is 'gardening' its own food source. The suspension-feeding bivalve displaced the same polychaete but had no positive effects on other benthos at the experimental site. In marine benthos, Hylleberg (1975) was the first to introduce the concept of gardening, and Gerlach (1978) suggested that it applies to interactions between zoobenthos and bacteria in general.

\section{MATERIAL AND METHODS}

\section{Habitat}

The experiments were done on a bare, sandy tidal flat ('Königshafen') at the eastern coast of the North Sea, close to the island of Sylt. Depth at high tide is $1.6 \mathrm{~m}$. Exposure to air is about $2 \mathrm{~h}$ per tidal cycle (semilunar). Annual mean water temperature is $10^{\circ} \mathrm{C}$ 
(summer 15.1 , winter $4.5^{\circ} \mathrm{C}$ ). Salinity remains close to $31 \% \mathrm{~S}$. Sand grains are mainly quartz with a median of $0.46 \mathrm{~mm}$ (phi $=1.14$ ) and a sorting coefficient of 1.5 . Organic content is $0.4 \%$ (dry weight).

The flat is dominated by the lugworm Arenicola marina L. (60 ind. $\mathrm{m}^{-2}$ ). Numerically, Nematoda are most important $\left(\begin{array}{lll}11 & 10^{5} \cdot \mathrm{m}^{-2}\end{array}\right)$ and primarily live in the upper $3 \mathrm{~cm}$ of sediment. In July/August 1981, the sediment was oxidized in the upper $0.5 \mathrm{~cm}$, below it was black.

\section{Experiments}

The tellinid Macoma balthica (L.) Iives buried in the sediment at 3 to $6 \mathrm{~cm}$ depth, and a long inhalant siphon is extended up to the surface where food particles are gathered. I collected 148 individuals with an average length of $12 \mathrm{~mm}$ (range 7 to $15 \mathrm{~mm}$; mean volume 0.3 $\mathrm{cm}^{3}$ ), washed them to remove adhering small fauna, and assembled them into 4 equal groups. These groups were transplanted into sediment, allowing $3 \mathrm{~cm}^{2}$ for each individual. To accomplish this without disturbing the sediment, I excavated sediment cores of $110 \mathrm{~cm}^{2}$ and $11 \mathrm{~cm}$ depth during low tide, cut off the top at 3.5 $\mathrm{cm}$, placed 37 tellinids evenly on the cross section, and then replaced the top layer.

When collecting Macoma balthica, I noted that most were oriented more or less horizontally in the sediment, Iying on their left side. In the Experiment I oriented them accordingly. Finally, the entire cores were fitted into appropriate containers made out of gauze (mesh size $1 \mathrm{~mm}$ ), open to the surface, and then were placed back into the tidal flat sediment. With 4 controls I did exactly the same but left out the tellinids.

A similar experiment was done with the suspensionfeeding cockle Cerastoderma (Cardium) edule (L.). Its siphons are short and apertures are flush with the surface. I collected 106 cockles with an average length of $18 \mathrm{~mm}$ (range 11 to $21 \mathrm{~mm}$; mean volume $2 \mathrm{~cm}^{3}$; age 2 yr), assembled them into 4 groups of 26 and 27 individuals, and placed them on areas of $110 \mathrm{~cm}^{2}$, allowing $4 \mathrm{~cm}^{2}$ for each cockle. Each area was surrounded by an anchored PVC-ring, flush with the sediment surface. All cockles quickly buried themselves. As controls, I placed 4 rings on the sediment, and made sure that no cockles were inside by raking the sediment with a finger.

\section{Sampling}

Both experiments were started on July 23,1981 . The cockle experiment was terminated after $22 \mathrm{~d}$, the tellinid experiment after $30 \mathrm{~d}$. Of the 4 Macoma-aggre- gates, 3 were sampled at the end of experiment. The fourth aggregate was used for pilot sampling and sediment analysis. I took 2 samples from each of 3 containers, together 6 controls and 6 from tellinid aggregates. Each sample was a sediment core of $2 \mathrm{~cm}^{2}$ and a depth of $8 \mathrm{~cm}$, divided into $1 \mathrm{~cm}$ intervals. Thus, a total of 96 $2 \mathrm{~cm}^{3}$ units of sediment were transported to the laboratory where they were sorted with respect to Turbellaria and Polychaeta. All tellinids still present in the containers were counted.

The cockle aggregates were sampled similarly. However, depth of cores was limited to $2 \mathrm{~cm}$ because pilot sampling revealed no Turbellaria deeper than this. In the aggregates, cockle siphons were visible at the surface and I took each sample adjacent to a cockle. Numbers of Cerastoderma edule were counted.

\section{RESULTS}

In July 1980 , a set of 6 parallel cores of $2 \mathrm{~cm}^{2} / 0-5 \mathrm{~cm}$ was taken, divided into $0.5 \mathrm{~cm}$ depth intervals. One core happened to include an individual Macoma balthica (11.5 mm long), positioned at a depth of $3.5 \mathrm{~cm}$. In that core, the vertical distribution of meiofauna (including large ciliates) was quite different compared to the other 5 (Fig. 1). Close to the surface, total abundance was as usual. Below $2 \mathrm{~cm}$ depth, however, abundance of Ciliata, Nematoda and Turbellaria increased considerably and remained high to a depth of $4 \mathrm{~cm}$, then abruptly decreased. In the other 5 cores, high abundance was limited to the upper $1.5 \mathrm{~cm}$ and then remained close to zero. The total abundance of small fauna below $2 \mathrm{~cm}^{2}$ was $280 \pm 49$ in the 5 normal cores, and 987 in the presence of $M$. balthica, a 3.5 fold increase. This pilot investigation led to the following experiments.

\section{Aggregates of Macoma balthica}

Tellinids were experimentally arranged into 4 aggregates, each with 37 individuals below $110 \mathrm{~cm}^{2}$. Gauze prevented lateral emigration but escape from the sediment was possible. This, or removal by predators, was negligible over the $30 \mathrm{~d}$ of experiment. I encountered $30,32,36$ and 36 individuals in the 4 containers. All were alive. In the controls and the tellinid containers, the upper $0.5 \mathrm{~cm}$ of sediment were brownish (= oxidized). Below this, the sediment in the control containers was black (= reducing). In the tellinid containers, numerous pockets of brownish and grey colour occurred in the depth range of 2 to $6 \mathrm{~cm}$. A $1 \mathrm{~mm}$ layer of brownish sediment surrounded most tellinids, and more extensive grey halos were always 


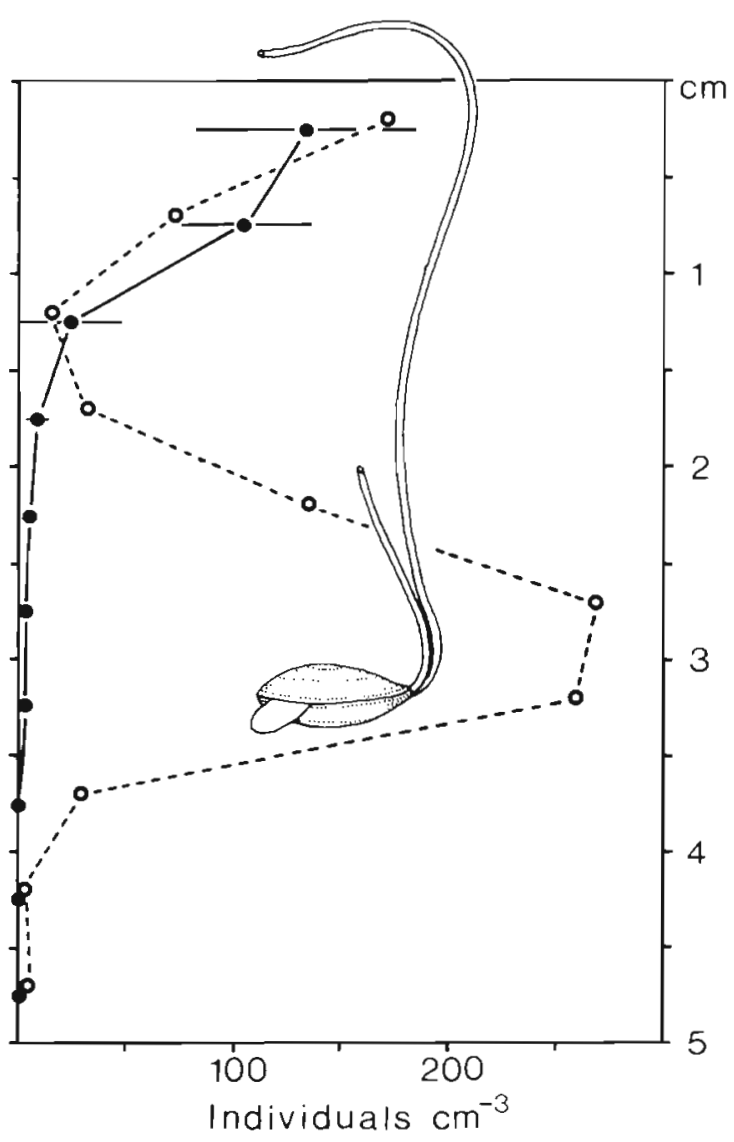

Fig. 1. Vertical distribution in $0.5-\mathrm{cm}$ intervals of small zoobenthos abundance (including Ciliata $>0.2 \mathrm{~mm}$ length) in the upper $5 \mathrm{~cm}$ of normal sediment (mean and standard deviation of 5 cores of $2 \mathrm{~cm}^{2}$ ) and in a single core (broken line) which happened to include an individual of Macoma balthica, positioned at $3.5 \mathrm{~cm}$ depth

present. Frequently, siphons were found within brownish or grey sediment but they also ran through completely black zones.

Turbellaria show a preference for the tellinid aggregates (Table 1). The difference between controls and aggregates is most pronounced in the subsurface com-

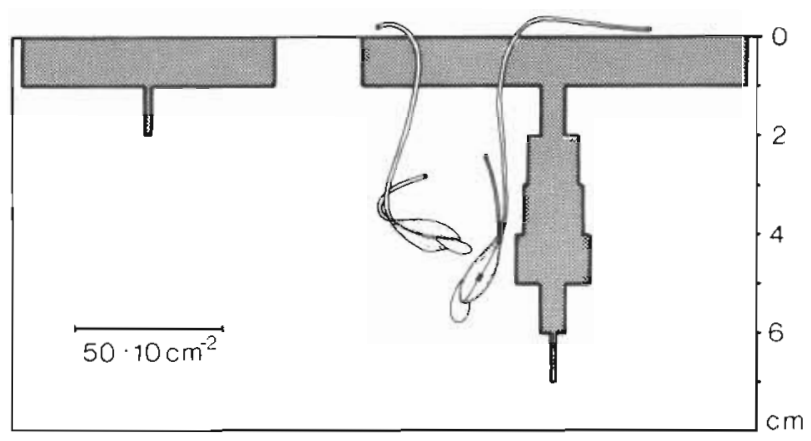

Fig. 2. Vertical distribution of turbellarian abundance in nomal sediment and within experimental aggregates of

Macoma balthica (right), positioned at 3 to $6 \mathrm{~cm}$ depth

ponent, but also at the surface Turbellaria are significantly more numerous within the experimental aggregates (Fig. 2). The same applies to species density and species richness. Other measures of diversity (Shannon-index, inverted Simpson-index, evenness) all tend to be lower within the tellinid aggregates. This is primarily due to 3 species achieving a strong dominance (together $54 \%$ ) within aggregates (Fig. 3), one at the sediment surface (Macrostomum pusillum), one over the entire vertical range (Archilopsis unipunctata), and one in the deep sediment (Neoschizorhynchus parvorostro).

All 3 trophic guilds of Turbellaria (bacteria-feeders, diatom-feeders, predators) contribute significantly to the increased abundance within tellinid aggregates (Table 1). Considering the upper $2 \mathrm{~cm}$ of sediment, only diatom-feeders are significantly more abundant. In bacteria-feeders and predators, it is primarily the subsurface component that contributes to the observed differences.

None of the turbellarian species is more abundant in the controls (Table 2). While diatom-feeders are confined to the sediment surface, many of the bacteriafeeders and predators colonize the subsurface when tellinids are present. The strong subsurface component

Table 1. Components of the turbeliarian assemblage in the absence of and within aggregates of Macoma balthica. Means (SD = standard deviation) of 6 samples of $2 \mathrm{~cm}^{2} / 0-8 \mathrm{~cm}$. $\mathrm{P}=$ probability of error when assuming higher values for Turbellaria in sediment with $M$. balthica (Mann-Whitney U-test)

\begin{tabular}{|c|c|c|c|}
\hline Individuals $2 \mathrm{~cm}^{-2}(\mathrm{SD})$ & $\begin{array}{c}\text { No } \\
\text { Macoma }\end{array}$ & $\begin{array}{l}\text { With } \\
\text { Macoma }\end{array}$ & $\begin{array}{c}\text { U-test } \\
\mathrm{P}\end{array}$ \\
\hline All Turbellaria in 0 to $8 \mathrm{~cm}$ depth & $17.3(7.1)$ & $41.7(5.8)$ & $<0.01$ \\
\hline in 0 to $2 \mathrm{~cm}$ depth & $17.3(7.1)$ & $27.3(7.4)$ & $<0.05$ \\
\hline in 2 to $8 \mathrm{~cm}$ depth & 0.0 & $14.4(7.4)$ & $<0.01$ \\
\hline Diatom-feeders (8 spp.) & $7.5(3.6)$ & $12.5(3.7)$ & $<0.05$ \\
\hline Bacteria-feeders (5 ssp.) & $2.0(1.1)$ & $7.3(2.7)$ & $<0.01$ \\
\hline Predators (23 spp.) & $7.7(3.8)$ & $21.0(8.1)$ & $<0.01$ \\
\hline Species richness $\left(12 \mathrm{~cm}^{2}\right)$ in 0 to $2 \mathrm{~cm}$ & 26 & 25 & \\
\hline in 0 to $8 \mathrm{~cm}$ & 0 & 11 & \\
\hline
\end{tabular}




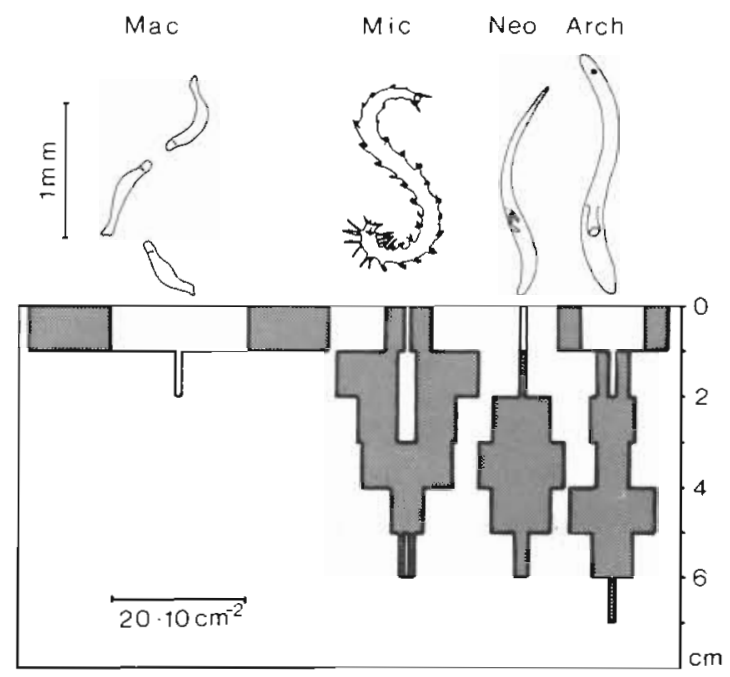

Fig. 3. Vertical distribution of species' abundances in normal sediment (white) and within aggregates of Macoma balthica (dark shaded with white areas inclusive). Light shading: layer where tellinids are positioned. Mac $=$ Macrostomum pusillum (diatom-feeder), Mic = Microphthalmus $2 \mathrm{spp}$. (diatomand bacteria-feeder), Neo $=$ Neoschizorhynchus parvorostro (bacteria-feeder), Arch $=$ Archilopsis unipunctata (predator)

of Turbellaria within the aggregates (Fig. 2 and 3 ) cannot be explained by simple downward migration from the surface layer. There are too few Neoschizorhynchus parvorostro at the surface to allow for the observed high numbers in 2 to $5 \mathrm{~cm}$ depth of aggregates. Archilopsis unipunctata increased in abundance at the surface as well as below. Nine turbellarian species of the subsurface component are completely missing at the surface. Immigration from external sources must be assumed.

Small Polychaeta also respond to the initiation of tellinid aggregates (Table 3). The interstitial Microphthalmus sczelkowii populates the transition zone between surface and subsurface when Macoma balthica is present (Fig. 3). This hesionid polychaete feeds on bacteria and microalgae. The tube-dwelling Pygospio elegans is significantly less abundant within Macoma-aggregates. Similar to the tellinid, this spionid feeds on small particles collected from the sediment surface. Another tube-dwelling polychaete, Spio filicornis, is not affected. Species density is higher within the aggregates compared to the controls, while total species richness is similar.

Within $30 \mathrm{~d}$, aggregates of Macoma balthica induced considerable increase in the abundance of the subsurface component of small Polychaeta and of Turbellaria, and in the latter group also in the surface component. Out of 48 turbellarian and polychaete species, only 1 significantly decreased in number within tellinid aggregates.

\section{Aggregates of Cerastoderma edule}

Most cockles moved out of the experimental aggregates within $22 \mathrm{~d}$. Out of the 26 or 27 cockles initially assembled to each of 4 aggregates, only 11 in 3 , and 8 in 1 were still present. The others crawled out and many of them were observed in the vicinity. Cockles generate no micro-oxic zones in the reduced subsurface sediment. Samples were taken from the 3 containers with 11 cockles each ( 1 cockle $10 \mathrm{~cm}^{-2}$ ). Turbellaria remained indifferent to these experimental aggregates of Cerastoderma edule (Table 4). However, they are considerably more patchy in distribution between cockles than elsewhere (Lloyd's index of patchiness).

Of small Polychaeta, none is significantly more abundant within cockle aggregates (Table 5). Pygospio elegans is sensitive also to the presence of this bivalve and abandoned the aggregates. This also applies to all 3 tube-building spionids combined. Probably, the crawling of cockles is harmful to tube-dwellers.

\section{DISCUSSION}

\section{Deposit-feeding in Macoma balthica}

Macoma balthica is reported to utilize detritus, bacteria, diatoms and protozoans as food (Wernstedt, 1942; Fenchel, 1972; Tunnicliffe and Risk, 1977). Investigators disagree whether $M$. balthica is an obligate deposit-feeder or also a suspension-feeder. Gilbert (1977) gives a thorough account of the functional morphology of feeding and concludes that $M$. balthica is adapted to deposit-feeding but not to suspension-feeding. Others observed the inhalant siphon pointing vertically upwards and concluded that suspension-feeding is a second mode (i.e. Brafield and Newell, 1961; Rasmussen, 1973). However, an erect siphon does not necessarily imply suspension-feeding. An incurrent of overlying water may be primarily for respiration or for rinsing. On the experimental site, I observed $M$. balthica deposit-feeding, sometimes even probing the siphon into the sediment. Only occasionally did a siphon point upwards.

\section{Competitive displacement}

Field experiments where 1 species is added to the natural assemblage are usually designed to test the effects of competition. In the present case, the tubedwelling polychaete Pygospio elegans abandoned the aggregates of both bivalves, Macoma balthica and Cerastoderma edule. This spionid polychaete feeds on small surface deposits as well as on suspended parti- 
Table 2. Species composition and abundance (individuals. $12 \mathrm{~cm}^{-2}$ ) of Turbellaria in the absence of and within aggregates of Macoma balthica. $\mathrm{D}=$ diatom-feeder, $\mathrm{B}=$ bacteria-feeder, $\mathrm{P}=$ predator

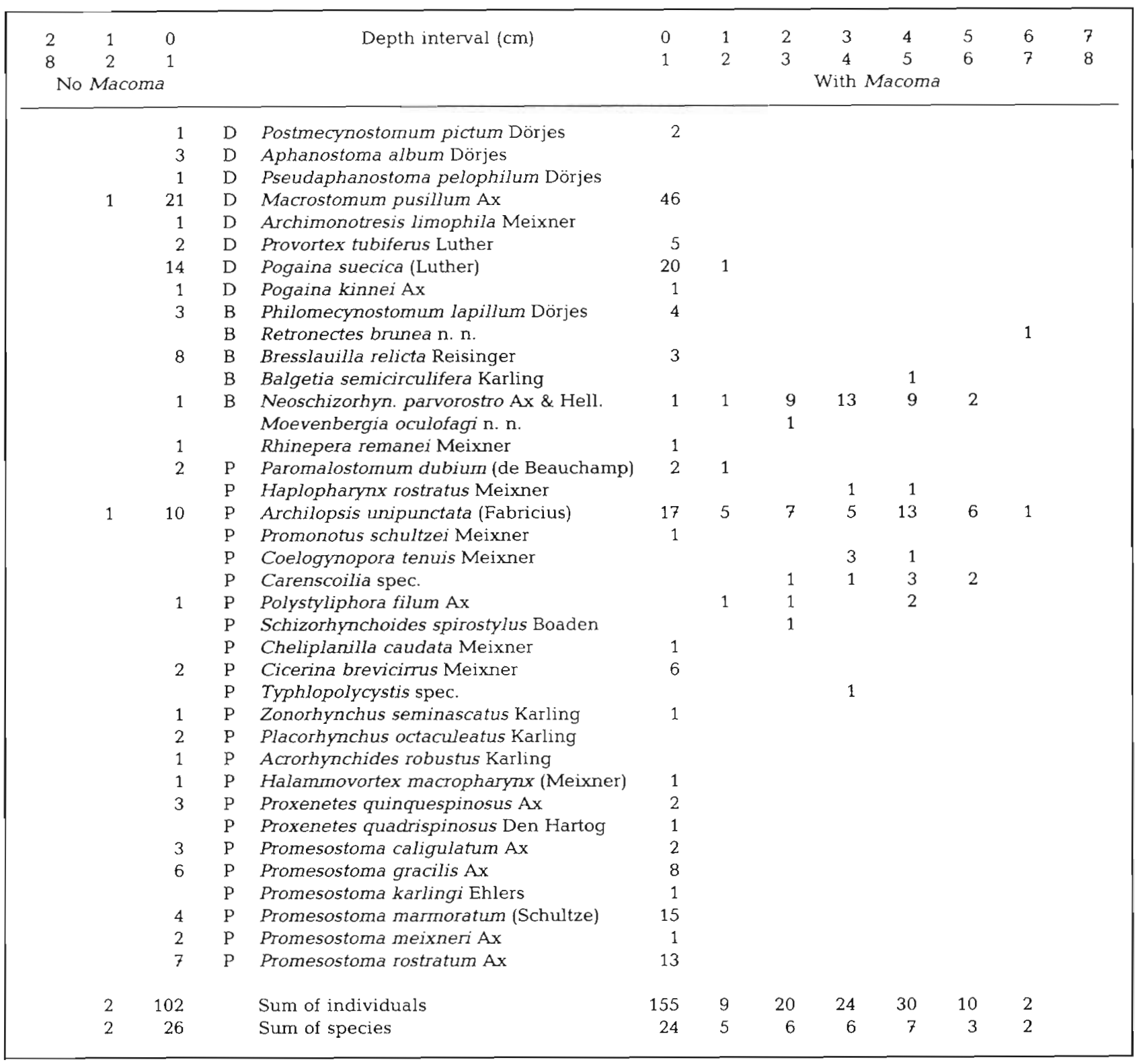

Table 3. Small Polychaeta in the absence of and within aggregates of Macoma balthica. Means (SD = standard deviation) of 6 samples of $2 \mathrm{~cm}^{2} / 0-8 \mathrm{~cm} . \mathrm{P}=$ probability of error when assuming a difference; $\mathrm{ns}=\mathrm{P}>0.05$ (Mann-Whitney U-test)

\begin{tabular}{|lrrr|}
\hline Individuals $2 \mathrm{~cm}^{-2}$ (SD) & $\begin{array}{c}\text { No } \\
\text { Macoma }\end{array}$ & $\begin{array}{c}\text { With } \\
\text { Macoma }\end{array}$ & $\begin{array}{c}\text { U-Test } \\
\text { P }\end{array}$ \\
\hline All Polychaeta & $14.3(4.8)$ & $19.7(8.6)$ & $\mathrm{ns}$ \\
Microphthalmus sczelkowii Mecznikow & $1.0(1.5)$ & $9.8(7.9)$ & $<0.05$ \\
Microphthalmus aberrans (Webster \& Ben.) & $0.3(0.5)$ & $1.3(1.5)$ & $\mathrm{ns}$ \\
Spio filicornis (O. F. Müller) & $2.5(3.3)$ & $3.5(1.6)$ & $\mathrm{ns}$ \\
Pygospio elegans Claparéde & $8.2(4.6)$ & $2.2(1.9)$ & $\mathrm{n}$ \\
Others (6 ssp.) & $2.3(2.0)$ & $2.9(1.8)$ & $<.9(0.9)$ \\
Species density & $4.3(1.6)$ & 9 & \\
Species richness $\left(12 \mathrm{~cm}^{2}\right)$ & 10 & & 9.05 \\
\hline
\end{tabular}


Table 4. Components of the turbellarian assemblage in the absence of and within aggregates of Cerastoderma edule. Means ( $\mathrm{SD}=$ standard deviation) of 6 samples of $2 \mathrm{~cm}^{2} / 0-2$ $\mathrm{cm}$. There are no significant differences (Mann-Whitney Utest)

\begin{tabular}{|lcc|}
\hline Individuals $2 \mathrm{~cm}^{-2}$ (SD) & $\begin{array}{c}\text { No } \\
\text { cockles }\end{array}$ & $\begin{array}{c}\text { With } \\
\text { cockles }\end{array}$ \\
\hline All Turbellaria & $21.0(6.6)$ & $21.5(8.3)$ \\
Diatom-feeders (6 ssp.) & $10.3(4.5)$ & $10.2(4.7)$ \\
Bacteria-feeders (5 spp.) & $2.0(2.1)$ & $2.2(1.8)$ \\
Predators (18 spp.) & $8.7(3.7)$ & $9.2(4.4)$ \\
Species density & $9.2(2.5)$ & $9.3(2.2)$ \\
Species richness (12 $\left.\mathrm{cm}^{2}\right)$ & 25 & 21 \\
\hline
\end{tabular}

Table 5. Small Polychaeta in the absence of and within aggregates of Cerastoderma edule. Means ( $\mathrm{SD}=$ standard deviation) of 6 samples of $2 \mathrm{~cm}^{2} / 0-2 \mathrm{~cm}$. $\mathrm{P}=$ probability of error when assuming a difference; ns $=\mathrm{P}>0.05$ (MannWhitney U-test)

\begin{tabular}{|lccc|}
\hline Individuals $2 \mathrm{~cm}^{-2}$ (SD) & $\begin{array}{c}\text { No } \\
\text { cockles }\end{array}$ & $\begin{array}{c}\text { With } \\
\text { cockles }\end{array}$ & $\begin{array}{c}\text { U-test } \\
\text { P }\end{array}$ \\
\hline All Polychaeta & $8.3(3.2)$ & $6.2(3.2)$ & $\mathrm{ns}$ \\
Microphthalmus sczelkowii & $0.7(1.0)$ & $2.7(4.3)$ & $\mathrm{ns}$ \\
Spio filicomis & $1.8(1.9)$ & $0.2(0.4)$ & $\mathrm{ns}$ \\
Pygospio elegans & $5.2(1.5)$ & $2.3(1.6)$ & $<0.05$ \\
Others (3 spp.) & 0.7 & 0.8 & $\mathrm{~ns}$ \\
Species density & $2.5(1.2)$ & $2.5(0.8)$ & $\mathrm{ns}$ \\
Species richness $\left(12 \mathrm{~cm}^{2}\right)$ & 5 & 6 & \\
& & & \\
\hline
\end{tabular}

cles (Hempel, 1957; Fauchald and Jumars, 1979). Thus there is an overlap with the food spectra of both bivalves. However, interference competition is more likely. Levin (1981, 1982) observed interference between spionid polychaetes (palp fighting) and I observed $P$, elegans to withdraw into its tube when touched by a siphon of $M$. balthica. Abundance of the related Spio filicornis was not affected by $M$. balthica, although it seems to feed in a similar way.

\section{Exhalant siphons below surface}

More conspicuous than this case of competition are the promotional effects of Macoma balthica on small fauna. High abundance of meiofauna in micro-oxic zones generated by macrofauna in the subsurface sediment are a general phenomenon, explained by the provision of oxygen and by an increased microbial activity serving as food to meiofauna (Aller and Yingst, 1978; Anderson and Meadows, 1979; Reise and Ax, 1979; Reise, 1981a, b).

Macoma balthica does not live in a burrow where overlying water is pumped downwards, as is the case with polychaetes. However, oxygenated zones can be observed where siphons penetrate the sediment and also directly at the bivalves (Thamdrup, 1935; Ankar, 1977; this study). In thin aquaria, Ankar observed 'a water current finding its way from the exhalant siphon back along the inhalant siphon to the sediment surface'. In his drawing (Fig. 7 in Ankar, 1977), the exhalant siphon terminates within the reduced sediment layer. Probably the sediment around siphons is worked loose, allowing oxygenated water to spread from the exhalant siphon. This may be a side effect of mobility, but it also partly prevents the poisoness hydrogen sulfide of the sediment from direct contact with the tellinid.

Crucial for this effect seems to be that the exhalant siphon of Macoma balthica does not extend to the sediment surface. In the Tellinacea, exhalant siphons are usually shorter than the inhalant ones (Yonge, 1949) but there are few accounts detailed enough to distinguish between a siphon termination below or flush with the surface. Tellina fabula and $T$. tenuis are depicted by Salzwedel (1979) and Trevallion (1971) respectively, with the exhalant siphon Iying horizontally within the sediment. Holme (1950), however, draws $T$. tenuis with the exhalant siphon extending to the surface. $M$. nasuta is reported to keep the exhalant siphon about $1 \mathrm{~cm}$ below surface (Hylleberg and Gallucci, 1975). Rasmussen (1973) and Gilbert (1977) show $M$. balthica with the aperture of the exhalant siphon flush with the surface. Ankar (1977) observed it to remain below surface, and so did I. Perhaps, this behaviour varies with sediment and locality, but more detailed observations are needed.

\section{Nutrient enrichment}

The termination of exhalant siphons below surface seems to be responsible for micro-oxic zones surrounding Macoma balthica. It will also produce localized concentrations of nutrients, notably nitrogen compounds. This will stimulate growth in microorganisms and diatoms. On sandy tidal flats where the experiment was done, Asmus (1982) measured nutrients and diatom growth and concluded that nitrogen compounds may be limiting to diatoms during summer. In July, ammonium and nitrate decreased down to zero. A siphon aperture flush with the surface, as in Cerastoderma edule, does not allow a localized effect under a tidal regime.

\section{Colonization of subsuriace sediment}

Ankar (1977) observed abundant naidids and nematodes close to siphons of Macoma balthica. In this 
study, high abundance of Ciliata, Nematoda, Turbellaria and small Polychaeta is documented. The species composition suggests that the experimental Macomaaggregates received their subsurface immigrants from the nearby burrows of the polychaete Arenicola marina (Reise and Ax, 1979; Reise, 1983). High numbers of the polychaete Microphthalmus sczelkowii and the bacteria-feeding Turbellaria in the subsurface sediment within Macoma-aggregates imply an increased amount of food in form of microorganism. The strong predatory component in Turbellaria documents that a 3-level trophic web (microorganisms - grazers - predators) is maintained by $M$. balthica below the sediment surface.

\section{Diatom-feeders at the surface}

Macoma-aggregates not only increased the subsurface meiofauna but also those dwelling in the surface layer. Turbellaria in general and diatom-feeders in particular are significantly more abundant within aggregates than in controls. Woodin (1978) observed more small fauna in the shelter of tube-caps of the polychaete Diopatra cuprea and interpreted this as a refuge from epibenthic predation. Other examples of high abundance are explained as responses to biotic disturbances in the form of feeding funnels, fecal mounds and diggings (Thistle, 1980; Reise, 1981b: VanBlaricom, 1982) or to biotically mediated sediment stability (Rhoads and Young, 1971).

None of these examples seems to explain high abundance of diatom-feeding Turbellaria within aggregates of Macoma balthica. I suppose that part of the nutrients released by the tellinid below the surface become available to the diatoms above. In addition, the high biological activity encouraged by $M$. balthica in the subsurface is likely to provide the surface layer with even more nutrients. In the cockle aggregates, where exhalant siphons discharge directly into the overlying water, no positive response of diatom-feeding Turbellaria is observed.

\section{Gardening}

Where there is more food for diatom-feeding and bacteria-feeding meiofauna, there should be more food for Macoma balthica too. Both have bacteria and diatoms as a common food source, and predatory Turbellaria prey on Ciliata, Nematoda, Copepoda and others which in turn feed on bacteria and diatoms. Thus, the observed distribution of trophic guilds in Turbellaria suggests that $M$. balthica stimulates the growth of its own food source. This effect has been termed 'gardening' in marine benthos and examples are feeding pockets of Abarenicola pacifica (Hylleberg, 1975) and mucus threads in nematodes (Riemann and Schrage, 1978; Warwick, 1981). In microcosms, Tenore and Rice (1980) added ciliates and meiofauna to deposit-feeding polychaetes. This not only enhanced mineralization but the polychaetes also increased their net incorporation rate of detritus. At moderate densities in microcosms, the mud snail $I l y_{y}$ anassa obsoleta stimulated diatom growth, possibly by accelerating nitrogen cycling (Connor et. al., 1982). Newell (1965) cultured faeces of Hydrobia ulvae and $M$. balthica and observed a rapid increase of the nitrogen content, attributed to bacterial growth on a favourable substrate.

Using Turbellaria and small Polychaeta as bioindicators, the present results demonstrate that Macoma balthica enriches the sediment with nutrients and thus cultures its own food source. Gerlach (1978) proposed that such 'gardening' is highly important in marine sediments.

The density of Macoma balthica in the experimental aggregates ( 1 individual $3 \mathrm{~cm}^{-2}$ ) which produced this 'gardening' effect is not an unrealistic one. In the Bay of Fundy, Tunnicliffe and Risk (1977) found 1 ind. 2.8 $\mathrm{cm}^{-2}$. In Britain, Fraser (1932) records 1 ind. $1.7 \mathrm{~cm}^{-2}$. At the experimental site, I found no more than 3 individuals below $1000 \mathrm{~cm}^{2}$, however, on adjacent flats in earlier years I recorded much higher densities (Reise, 1978; own unpubl. data). Beukema et. al. (1977) found that highest growth rates coincide with highest density in $M$. balthica. A result to be expected under the hypothesis of 'gardening'.

Acknowledgements. The hospitality of the Biologische Anstalt Helgoland, Litoralstation List is kindly acknowledged.

\section{LITERATURE CITED}

Aller, R. C. Yingst, J. Y. (1978). Biogeochemistry of tubedwelling: a study of the sedentary polychaete Amphitrite omata (Leidy). J. mar. Res. 36: 201-254

Anderson, J. G., Meadows, P. S. (1978). Microenvironments in marine sediments. Proc. R. Soc. Edinb. 76B: 1-16

Ankar, S. (1977). The soft bottom ecosystem of the Northern Baltic proper with special reference to the macrofauna. Contr. Askö Lab. 19: 1-62

Asmus, R. (1982). Field measurements on seasonal variation of the activity of primary producers on a sandy tidal flat in the northern Wadden Sea. Neth. J. Sea Res. 16: 389-402

Brafield, A. E., Newell, G. E. (1961). The behaviour of Macoma balthica (L.). J. mar. biol. Ass. U. K. 41: 81-87

Beukema, J. J., Cadée, G. C., Jansen, J. J. M. (1977). Variability of growth rate of Macoma balthica (L.) in the Wadden Sea in relation to availability of food. In: Keegan, B. F., Céidigh, P. O., Boaden, P. J. S. (ed.) Biology of benthic organisms. Pergamon Press, New York, p. 69-77

Connor, M. S., Teal, J. M., Valiela, I. (1982). The effect of 
feeding by mud snails, Ilyanassa obsoleta (Say), on the structure and metabolism of a laboratory benthic algal community. J. exp. mar. Biol. Ecol. 65: 29-45

Fauchald, K., Jumars, P. A. (1979). The diet of worms: a study of polychaete feeding guilds. Oceanogr. mar. Biol. A. Rev. 17: $193-284$

Fenchel, T (1972). Aspects of decomposer food chains in marine benthos. Verh. dt. zool. Ges. 65: 14-22

Fraser, J. H. (1932). Observations on the fauna and constituents of an estuarine mud in a polluted area. J. mar. biol. Ass. U. K. 22: 69-85

Gerlach, S. A. (1978). Food-chain relationships in subtidal silty sand marine sediments and the role of meiofauna in stimulating bacterial productivity. Oecologia (Berl.) 33: 55-69

Gilbert, M. A. (1977). The behaviour and functional morphology of deposit feeding in Macoma balthica (L.) in New England. J. mollusc. Stud. 43: 18-27

Hempel, C. (1957). Über den Röhrenbau und die Nahrungsaufnahme einiger Spioniden (Polychaeta Sedentaria) der deutschen Küsten. Helgoländer wiss. Meeresunters. 6: 100-135

Holme, N. A. (1950). Population-dispersion in Tellina tenuis Da Costa. J. mar. biol. Ass. U. K. 29: 267-280

Hylleberg, J. (1975). Selective feeding by Abarenicola pacifica with notes on Abarenicola vagabunda and a concept of gardening in lugworms. Ophelia 14: 113-137

Hylleberg, J., Gallucci, V. F. (1975). Selectivity in feeding by the deposit-feeding bivalve Macoma nasuta. Mar. Biol. 32: $167-178$

Levin, L. A. (1981) Dispersion, feeding behaviour and competition in two spionid polychaetes. J. mar. Res. 39: 99-117

Levin, L. A. (1982). Interference interactions among tubedwelling polychaetes in a dense infauna assemblage. J. exp. mar. Biol. Ecol. 65: 107-119

Newell, R. C. (1965). The role of detritus in the nutrition of two marine deposit feeders, the prosobranch Hydrobia ulvae and the bivalve Macoma balthica. Proc. zool. Soc. 144: $25-45$

Rasmussen, E. (1973). Systematics and ecology of the Isefjord marine fauna (Denmark). Ophelia 11: 1-495

Reise, K. (1978). Experiments on epibenthic predation in the Wadden Sea. Helgoländer wiss. Meeresunters. 31: 55-101

Reise, K. (1981a). Gnathostomulida abundant alongside polychaete burrows. Mar. Ecol. Prog. Ser. 6: 329-333

Reise, K. (1981b). High abundance of small zoobenthos around biogenic structures in tidal flat sediments of the Wadden Sea. Helgoländer Meeresunters. 34: 413-425
Reise, K. (1983). Turbellaria of a marine sand flat: an ecological study Mikrofauna mar. 1 (in press)

Reise, K., Ax, P. (1979). A meiofaunal 'thiobios' limited to the anaerobic sulfide system of marine sand does not exist Mar. Biol. 54: 225-237

Rhoads, D. C., Young, D. K. (1971). Animal-sediment relations in Cape Cod Bay, Massachusetts. II. Reworking by MoIpadia oolitica (Holothuroidea). Mar. Biol. 11: 255--261

Riemann, F., Schrage, M. (1978). The mucus-trap hypothesis on feeding of aquatic nematodes and implications for biodegradation and sediment texture. Oecologia (Berl.) 34: $75-88$

Salzwedel, H. (1979). Reproduction, growth, mortality, and variations in abundance and biomass of Tellina fabula (Bivalvia) in the German Bight in 1975/76. Veröff. Inst Meeresforsch. Bremerh. 18: 111-202

Tenore, K. R., Rice, D. L. (1980). A review of trophic factors affecting secondary production of deposit-feeders. In: Tenore, K. R., Coull, B. C. (eds.) Marine benthic dynamics. Univ. South Carolina Press, Columbia, S. C., p. 325-340

Thamdrup, H. M. (1935). Beiträge zur Okologie der Wattenfauna - auf experimenteller Grundlage. Meddr Danm. Fisk.-og Havunders. (Fiskeri) 10 (2): 1-125

Thistle, D. (1980). The response of a harpacticoid copepod community to a small-scale natural disturbance. J. mar. Res. 38: 381-395

Trevallion, A. (1971). Studies on Tellina tenuis Da Costa III Aspects of general biology and energy flow. J. exp. mar. Biol. Ecol. 7: 95-122

Tunnicliffe, V., Risk, M. J. (1977). Relationships between the bivalve Macoma balthica and bacteria in intertidal sediments: Minas Basin, Bay of Fundy. J. mar. Res. 35: 499-507

VanBlaricom, G. R. (1982). Experimental analyses of structural regulation in a marine sand community exposed to oceanic swell. Ecol. Monogr. 52: 283-305

Warwick, R. M. (1981). Survival strategies of meiofauna. In: Jones, N. V., Wolff, W. J. (ed.) Feeding and survival strategies of estuarine organisms. Plenum Press, New York, p. 39-52

Wernstedt, C. (1942). Studies on the food of Macoma balthica and Cardium edule. Vidensk. Meddrdansk naturh. Foren. 106: $241-252$

Woodin, S. A. (1978). Refuges, disturbance, and community structure: a marine soft-bottom example. Ecology 58: $274-284$

Yonge, C. M. (1949). On the structure and adaptations of the Tellinacea, deposit feeding Eulamellibranchia. Phil Trans. R. Soc. B $234: 29-76$ 